\title{
Bir Yumuşak Güç Kaynağı Olarak Türkiye'deki Çin Medyası
}

\author{
Chinese Media in Turkey as a Means of Soft Power
}

\author{
Yrd. Doç. Dr. Veli Boztepe
}

\section{Öz}

Son yillarda küresel ekonomide güçlü bir aktör haline gelen Çin; gücünü "yumuşak güç" kaynaklarıyla desteklemek için yoğun bir çaba harcamaktadır. Yumuşak güç stratejisinin "dışa açılmaya" dönüşmesiyle birlikte, medya yeniden yapılandirılmış, yeni strateji ekseninde kullanılmaya başlanmıştır. Çin, imajını yeniden inşa etmek amaciyla Türkiye'de de medyay kullanmaktadir. Çin yönetimi, Türkiye'de televizyon, radyo, dergi gibi geleneksel medyanin yanında yeni medyay da etkili bir biçimde hayata geçirmiştir. Makalenin temel varsayımı, Çin'in yumuşak güç stratejisi tam olarak anlaşılmadan Türkiye'deki medya faaliyetlerinin anlaşllamayacağl; Çin’in Türkiye'deki medya faaliyetlerini bu strateji çerçevesinde gerçekleştirdiğidir. Çalışma, Çin’in, Türkiye'deki medyaya yatırımlarını, "yumuşak güç" kavramina odaklanarak incelemektedir. Bu çerçevede, Çin'in Türkiye'deki yayınları klasik niteliksel inceleme yöntemiyle analiz edilmiştir. Çalışmada, Çin medyasının Türkiye'deki yayınlarının tarihsel gelişimi, hangi medya araçlarının daha fazla kullanıldiğı, ne tür programlarla hangi mesajların verildiği üzerinde yoğunlaşılmıştır. Bu kapsamda, Çin'in Türkiye kamuoyuna yönelik yaptığ 1 radyo, televizyon, dergi ve yeni medya yayınları incelenmiş, ayrıca doküman analizi ve görüşmeler yapılmıştır. Çalışma kapsamında, Çin’in Türkiye'deki medya faaliyetlerinin, yumuşak güç stratejisi ve 2001 yılında açıkladığı medyada "dışa açılma" stratejisiyle uyumlu olduğuna yönelik bulgulara ulaşılmıştır. Çin'in bu strateji çerçevesinde, "barış̧̧ıl, yardımsever, insan haklarına saygll ve gelişmiş bir ülke" imajını yerleştirmeye çalıştığı sonucuna ulaşılmıştır.

\begin{abstract}
China, which has become a powerful actor in the global economy in recent years, has been striving to increase its power through mobilizing various mechanisms of "soft power." In combination with its opening up policy, it has re-structured the state media industry and begun to use it as a part of "soft power" strategy at the global level. It also benefits from its investments in the media industry in Turkey in order to re-construct its image. In this respect, it has made important investments not only in the traditional media but also in the "new media" in the last five years. This article mainly argues that the media investments and activities of the Republic of China cannot be understood without an eye to its new strategy of enhanced soft power, which underlies all its endeavors in the media industry in Turkey. Therefore, this study examines China's media investments in Turkey by focusing upon the concept of soft power. For this purpose, these investments have been scrutinized by using a classical qualitative methodology. The contents of the Chinese media in Turkey have been examined in detail in terms of its policy of enhanced soft power. The main finding of the study is that China's media activities in Turkey are congruent with its strategy of soft power and its policy of opening up of the media, which the Chinese authorities put into effect in 2001. Through this strategy, China has deployed its media in Turkey to construct the image of a "peaceful, humanitarian, and developed" country.
\end{abstract}

Keywords: Soft Power, Media, China, Turkey

Anahtar Kelimeler: Yumuşak Güç, Medya, Çin, Türkiye

Yrd. Doç. Dr. Veli Boztepe, Okan Üniversitesi Meslek Yüksekokulu, veliboztepe@hotmail.com 


\section{Giriş}

Gelişen ekonomik, politik ve askeri bir güç olarak son yıllarda adından sıkça söz ettiren Çin, kimi akademisyen ve düşünürler tarafından geleceğin "süper gücü” olarak gösterilmektedir. Ancak, ekonomik olarak gelişmişlik ve sert güç kaynaklarına sahip olmak günümüzde bir ülkenin süper güç olması için yeterli değildir. Bu gerçeğin farkında olan Çin yönetiminin, son yıllarda "yumuşak güç" kaynaklarını sistemli bir biçimde devreye soktuğu görülmektedir. Çin yönetimi ülke içinde ve özellikle de ülke dışında imajını geliştirmek için yoğun çaba sarf etmektedir. Bir yandan uluslararası kamuoyunda ilerici, kültürel olarak gelişmiş ve barışsever bir ülke imajını yerleştirmeye çalışan Çin, diğer yandan anti demokratik uygulamalarda bulunduğu, insan hakları ihlalleri yaptığı, basın üzerinde baskı kurduğu, dinsel özgürlüklere sınırlama getirdiği gibi batı merkezli ithamlarla zedelenen imajını onarmaya çabalamaktadır. Çin’in; ekonomik ve diplomatik ilişkilerin gelişmesine paralel bir biçimde, Türkiye'deki "yumuşak güç" kaynaklarını da sistemli bir biçimde kullandığ 1 görülmektedir. Medya, Çin'in kendisini Türkiye kamuoyuna tanıtmak amacıyla kullandığı temel yumuşak güç aracıdır.

$\mathrm{Bu}$ çalışmanın amacı, Çin’in, Türkiye'de medyayı -yumuşak güç aracı olarak- kullanma biçiminin incelenmesidir. Bu çerçevede, Çin'in Türkiye'deki yayınları klasik niteliksel inceleme yöntemiyle analiz edilmiştir. Türkiye'deki Çin medyasının yayın içerikleri, Çin'in yumuşak güç stratejisi çerçevesinde incelenmiş ve yorumlanmıştır. Çalışma kapsamında, medyanın bir "yumuşak güç" aracı olarak çok önemli olduğu varsayımı ile Çin medyasının Türkiye’deki yayınlarının tarihsel gelişimi, hangi medya araçlarında yoğunlaştığı, ne tür programlarla hangi mesajların verildiği üzerinde yoğunlaşılmıştır. Bu kapsamda, Çin'in Türkiye kamuoyuna yönelik yaptığı tüm radyo, televizyon, dergi ve yeni medya yayınları incelenmiştir. İncelemede, medyanın "yumuşak güç" aracı olarak kullanımında ön planda olan haber bültenleri ve haber yorumlar üzerinde ayrıntılı olarak durulmuştur. Çin'in haberlerde hangi mesajları ön plana çıkardığını saptamak amacıyla haber başlıkları sınıflandırılarak incelenmiştir.

Radyo ve internet sayfası sayısının fazla olması nedeniyle, bu iki medya aracından örneklem seçilmiştir. Çin kaynaklı haber ve programlara tüm gün yer verdiği için Radyo Mega radyolar arasından, içerik açısından diğer internet sitelerine öncülük etmesi ve daha kapsamlı olması nedeniyle "http://turkish.cri. cn" internet siteleri arasından örneklem olarak alınmıştır. Radyo Mega ve "http://turkish.cri.cn" internet sitesinin yayın içerikleri 21-28 Mayıs 2015 tarihleri arasında ayrıntılı olarak incelenmiştir. CTV'nin yayınları da aynı tarihler arasında tüm gün izlenerek incelenmiştir. China Today Türkiye dergisi ise 1,4, 8, 12 ve 16. sayıları örneklem alınarak analiz edilmiştir. İnceleme kapsamında ele alınan yayınların izleyicidinleyici-okuyucu üzerindeki etkileriyle ilgili bir alan çalışması yapılmamıştır. Bu tür bir çalışma, ileriye yönelik çalışmalarda hedeflemekte ve diğer araştırmacılara da önerilmektedir.

Çalışma üç bölümden oluşmaktadır. Birinci bölümünde genel olarak yumuşak güç tanımlanmış, yumuşak güç kaynaklarına değinilmiş, yumuşak güçmedya ilişkisi ele alınmıştır. İkinci bölümde Çin’in "Yumuşak Güç" unsuru olarak uluslararası medya politikalarına değinilmiştir. Üçüncü bölümde Çin Medyasının Türkiyede çalışmaları yumuşak güç kavramı çerçevesinde ele alanmış ve çalışma sonuç bölümü ile sonlandırılmıştır.

\section{Yumuşak Güç Kavramı ve Yumuşak Gücün Kullanımında Medya}

\section{Yumuşak Güç}

Uluslararası örgütlerin yaygınlaşması, küresel medyanın gelişimi ve yeni aktörlerin ortaya çıkmasıyla birlikte uluslararası ilişkilerde gücün niteliği değişmeye başlamıştır (Özdemir, 2008, s. 113). Son yillarda uluslararası rekabette sert güç kaynaklarından ziyade yumuşak güç kaynakları kullanılmakta; diğer bir deyişle artık askerler ve silahlardan ziyade düşünceler öne çıkmaktadır. Resmi diplomasi gibi ülke çıkarlarını sağlamaya yönelik bir fikirler savaşı olan bu savaş, yabancı halkları anlayarak, bilgilendirerek ilişki kurarak ve etkileyerek kazanılır (Yılmaz, 2012, s. 202). Sert güç kavramı bir aktörün ekonomik ve askeri olanaklarını kullanarak başka bir aktör veya aktörlerin davranışları üzerinde değişiklik yapabilme veya nüfuz sağlayabilme becerisine işaret eder. Bunun yapılabilmesi için de kandırmalara (havuç) veya tehditlere (sopa) ihtiyaç vardır (Nye, 2005, s.14). Bir aktörün havuç ya da sopalara başvurmadan, işbirliği yaparak ya da çekicilik unsurlarını kullanarak istediklerini yaptırabilmesi ise, yumuşak güç olarak tanımlanır (Çavuş, 2012, s. 24). Yumuşak güç kav- 
ramını ilk kez 1990 yılında dile getiren Harvardlı siyaset bilimci Joseph Nye, kavramı "insanları, zor kullanmadan kendi tarafımıza çekme kabiliyeti" anlamında kullanır (Nye, Aktaran: Thussu, 2014, s. 5). Nye’e göre yumuşak güç, "bir ülkenin dünya siyasetinde isteği sonuçlara, onun değerlerine hayran olan, onu örnek alan, refah seviyesine ve firsatlarma özenen ülkelerin kendisini izlemesiyle ulaşmasıdır" (Nye, 2005, s. 14). Bu anlamda, 21. yüzyılda kimin ordusunun kazandığından ziyade, kimin hikâyesinin kazanacağ daha önemli olacaktır (Nye, 2010).

Yumuşak güç, davranış spektrumu olarak gündemi yaratma, cazibe ve yanına çekmeyi kullanır. Kurumlar, değerler, kültür ve politikalar yumuşak gücün başlıca kaynakları arasındadır (Çavuş, 2012, s. 24). Kültür ve tarih, değerler, devletlerin izledikleri iç ve dış politikalar, kurumlar, ekonomik gelişmişlik, bilim, sanat ve edebiyatta ilerlemişlik gibi unsurlar, yumuşak gücün önemli kaynakları arasında sayılmaktadır (Çavuş, 2012, s. 26). Dış politikada bu kaynakları kullanarak yumuşak güç stratejisi izlemenin belirli birtakım yolları vardır. Küresel veya bölgesel norm olabilecek statüde değerlere sahip olmak ve bunları yaymak, tanınmış ünlüler ya da kahramanlar vasıtasıyla mesajlar iletmek, ulusal veya küresel olmak üzere, çekiciliği olan söylemler yapmak bunların sadece birkaçıdır (Lee, Aktaran: Çavuş, 2012, s. 26).

Yumuşak gücün en önemli araçlarından biri de hiç kuşkusuz medyadır. İletişim araçlarının yaygınlaşması sonucu, yumuşak güç savaşında önem ve öncelik kazanan (Yllmaz, 2011, s. 34) medya günümüzde de yumuşak güç inisiyatiflerinde merkezi önemini korumaktadır (Thussu, 2014, s. 6). Yumuşak güç kullanımında medyanın rolünü daha iyi kavrayabilmek için, küresel medya alanında, özellikle de televizyon alanındaki gelişmeleri kısaca değerlendirmek yararlı olacaktır.

\section{Yumuşak Güç ve Medya}

Medya, özellikle de radyo ve televizyon, küresel etkinlik açısından önemli bir mekanizmadır. Medyanın ilk önceliği bir etki, ikna, kendini olumlu gösterme, taraftar toplama ve hedef kitleyi kendisine sempatik hale getirme ve de en önemlisi kendi görüş ve düşüncelerine uygun bir kamuoyunu; yaratmayı amaçlamaktadır. Bu araçlar, yüz milyonlarca insana ulaşabilme, insanları yönlendirme ve etkileme gücüne sahiptir İletişim araçlarının yaygınlaşması sonucu, günümüzde medya yoluyla yapılan savaşlar önem ve öncelik kazanmıştır (Yllmaz, 2011, s. 35). Nye’e göre; bilgi çağında yumuşak güce sahip olacak ülkelerde bulunması gereken niteliklerden biri etki ve gündem oluşturacak global iletişim kanallarıdır (Nye, 2002, s. 6). Uluslararası medya, kamu diplomasisi faaliyetlerinde yaygın olarak kullanılan ve yabancı kamuoylarını etkileme ve gündem oluşturma konusunda en etkili olan araçtır. Bu nedenle gelişen teknoloji ile birlikte bilginin hızlı bir şekilde dağılımı ve yönetimi sürecinde medya, devletler açısından daha fazla önem taşımaya başlamıştır (Kunczik, Aktaran: Sak, 2014, s. 14). Kamu diplomasisi faaliyetlerinde, devlet merkezli medyanın yanında tecimsel medya da kullanılmaktadır. Bunun en büyük örneği olarak, CNN ve Fox Tv gibi Amerikan kanalları verilebilir. Bunun yanı sıra devlet destekli BBC'nin de uluslararası arenada İngiliz çıkarlarının temsilcisi olduğunu söylemek yanlış olmayacaktır (Ertekin, 2012 s. 334). Diğer ülkelerde, medyadaki benzeri görülmemiş gelişmeye rağmen, küresel medyadaki en büyük gelişmeyi ABD medyası kaydetmiştir. Bugün de küresel medya ABD'nin hâkimiyetindedir. Politik, ekonomik, teknolojik ve askeri alanlardaki muazzam gücü nedeniyle Amerikan ve "Amerikanlaşmış" medya, küresel boyutta gerek İngilizce gerekse faaliyet gerçekleştirdiği ülkelerin diliyle etkinliklerini sürdürmektedirler. Bu durumda özellikle Amerikảnın uydular ve telekomünikasyon ağlarını büyük ölçüde kontrol etmesi önemli rol oynamaktadır (Thussu, 2014, s. 6). Ancak, medyayı yumuşak güç aracı olarak kullanma konusunda ABD’nin artık güçlü rakipleri vardır. ABD’nin rakiplerinin başında hiç kuşkusuz Çin gelmektedir. Çin, dönüşümünün en önemli enstrümanlarından biri olan medyayı; Afrika ülkeleri (Bu konudaki çalışmalar için bkz. Yanqiu 2014, Gagliardone, Repnikova ve Stremlau, 2010, Yick, 2013), başta olmak üzeri dünyanın bir çok ülkesinde etkili bir biçimde kullandığı görülmektedir. Çin’in medya alanındaki faaliyetlerinin Türkiye’de de hızla yayıldığı gözlenmektedir.

\section{Çin'in "Yumuşak Güç" Unsuru Olarak Uluslararası Medya Politikaları}

Çin gibi yükselen güçler için, yumuşak güç ve imaj yönetimi diplomasilerinin temel görünümleridir. Çin için yumuşak güç, dünya kamuoyunda güçlenmesini mümkün hale getirecek olan; siyasi modeli ve politikalarına anlayış, saygı ve sonunda destek oluşturacak bir güçtür. Yumuşak güç ayrıca kendisine yeni dostlar 
ve müttefikler kazandıracaktır (D'Hooghe, 2010, s. 1). Ancak, Çin'in yumuşak güç kullanımı konusunda hala önemli eksiklikleri vardır. Bu sorunlardan biri ülkenin yumuşak gücüyle sert gücü arasındaki dengesizliktir. Çin yönetimi ülkenin yumuşak gücüyle sert gücü arasında bir dengesizlik (ya da uyumsuzluk) olduğunun bilincindedir (Jian Wang, 2011, s. 5). Çin yöneticileri de ülkelerinin ekonomik olarak güçlü olması gerektiğini, ancak daha da önemlisi kültürel olarak güçlenmesi gerektiğine vurgu yapmaktadırlar (Fook, 2010, s. 549).

Ekonomik gücünün, "süper güç" olmak için yeterli olmadığının farkında olan Çin, kültürel diplomasi ve medya aracılı̆̆ıyla uluslararası imajını iyileștirmek için çabalarını son on yılda katlayarak arttırmıştır (Yanqiu, 2014). Çin'in, söyleminde nispeten yeni bir kavram olan "Yumuşak güç"ü (Hongying Wang, 2011, s. 37) son yıllarda oldukça etkili kullandığı göze çarpmaktadır. Açılılı ve şeffaflık algısının yumuşak gücün başarısında anahtar rol oynadığını (Zhu, 2012, s. 7) dikkate alan Çin'in yumuşak güç anlayışı 1990 yılından itibaren, "açmaktan (sınırlarını)" "dışa açılmaya” dönüşmüştür (Li ve Ronning, 2013 Aktaran: Yanqiu, 2014). Çin, hakkındaki ön yargıları yıkabilmek ve güven kazanmak için uluslar arası arenada görünür olmaya, diş dünyaya güvenilir, işbirliğine yatkın, barışçl ve gelişmiş bir ülke imajı vermeye çalışmaktadır (www.worldpublicopinion.org/pipa/ pdf/mr07/BBC_ViewsCountries_Mar07_pr.pdf, Aktaran: Akçadağ, 2011). Çin'in, yerleştirmeye çalıştığ bir başka imaj ise "yardımsever" imajıdır (Zhu, 2012, s.7).

Pekin, önde gelen kamu diplomasisi araçlarından biri olan medyaya büyük önem vermektedir (Kurlantzic, Aktaran: Akçadağ, 2011). Bir çok batı ülkesi haber endüstrilerini acımasız ekonomik yarışın insafına bırakırken, Çin uzun vadeli-stratejik medya yatırımları yapmaktadır (Nelson, 2013, s. 32). Ancak, Çin'in kamu diplomasisi için yapılan "güvenilirlik eksikliği" (D’Hooghe, 2010, s. 30) eleştirisi, medyası için de geçerlidir. Çin bu eksikliği gidermek ve $B B C, C N N, E l$ Cezire gibi uluslararası yayın yapan kanallarla rekabet edebilmek amacıyla yayıncılığa milyonlarca dolar bütçe ayırmaktadır (D’Hooghe, 2010, s 31).

Çin’in kendisini dışarıda tanıtmak için kullandığı en temel araçlardan biri olan medya faaliyetleri için dört temel organizasyon bulunmaktadır: Xinhua, China Central Television, China Radio İnternational, China Daily (Li, Aktaran: Sak, 2014, s. 21). Bu dört organizasyon daha sonra kurulacak medya organizasyonlarına da temel oluşturmuştur.

2001 yılında dönemin Çin devlet başkanı Jiang Zemin'in "Çin'in sesini tüm dünyaya yayalım” açıklamasının ardından Çin’nde Radyo, Televizyon ve Film konularındaki en üst kuruluş SARFT (The State Administration of Radio Film and Television) dişa açılma projesini başlatmıştır (Zhu, 2012, s. 32). Proje, beş yılda denizaşırı ülkelerde Çin radyo ve televizyon kanalları kurulmasını, on yılda ise çok dilli, yerelleştirilmiş-bölgeselleştirilmiş yayıncılık ve habercilik yapılmasını kapsamaktaydı. Çin medyası, $C N N, B B C$ ve diğer Batı medya şirketleriyle aynı küresel alanın bir oyuncusu haline gelecekti. Dışa açılma stratejisi Çince Uluslararası yayın yapan CCTV-4 ve İngilizce uluslararası yayın yapan CCTV-9'u içermekteydi (Zhu, 2012, s. 32).

Geleneksel medyanın yanında Çin, interneti de etkili bir biçimde kamu diplomasisi aracı olarak kullanmaktadır. Mayıs 2011'de kurulan the Xinhuanet Corporation LTD, Çince'nin yanı sıra İngilizce, Fransızca, İspanyolca, Arapça, Japonca, Korece, Tibetçe ve Uygurca dillerinde internet yayıncılığı yapmaktadır (http://news.xinhuanet.com). Ayrıca, People's Daily, Shanghai Daily, Caixin Online, Global Times ve benzeri çok sayıda İngilizce yayın yapan internet sitesi bulunmaktadır. Enformasyon Ofisi tarafindan kamu diplomasisi amacıyla düzenlenen siteler söz konusu dillerde Çin hakkında bilgiye erişim sağlamaktadır (Lejli, Aktaran: Sak, 2014, s. 22). Bu sayfalar Çin dili ve kültürü hakkında bilgilere, Çin ile ilgili güncel haberlere, resmi bilgilere veya Tibet Bölgesi gibi spesifik konulara yer vermektedir (Akçadağ, 2014). Bununla birlikte Çin sosyal medyayı da etkili bir şekilde kullanmaktadır.

Çin'in medyayı kullanımı devlet medyasıyla sınırlı değildir. Son on yılda özellikle Afrika’da çok fazla görünür hale gelen Çin medyası, CCTV Africa, China Daily Africa Weekly, Beijing Review, Xinhua News Agency, China Radio International (CRI) gibi devlet medyasının yanında özel dijital Televizyon platformları ve özel bir gazete olan Star Times'la da yayın yapmaktadır (Yanqiu, 2014). 


\section{Türkiye'de Çin Medyası: Tarihsel ve Kuramsal Bakış}

Çin Halk Cumhuriyeti ile Türkiye Cumhuriyeti arasındaki ekonomik, siyasi, kültürel ilişkiler son yıllarda hızla geliştirmeye başlamıştır. İlişkilerin genel seyrine bakıldığında hem siyasi hem de ekonomik olarak Çin'in belirlediği çerçeve içerisinde ilerlediği görülmektedir (Çolakoğlu, 2012, s. 64).

Türkiye ve Çin arasındaki ekonomik, diplomatik ve kültürel ilişkilerin gelişmesine paralel bir biçimde medya alanındaki işbirliği ve yatırımların da hızla geliştiği, ancak bu alanda da Çin’in mutlak hâkimiyetinin olduğunu söylemek yanlış olmayacaktir.

Bu bölümde Çin Türkiye ilişkilerine kısaca değinilecek, ardından Çin'in Türkiye'deki medya yatırımlarına ayrıntılı olarak incelenecektir.

\section{Türkiye-Çin İlişkileri}

Türkiye’nin Çin ile ilişkileri resmen başladığı günden bu güne kadar dalgalı bir seyir takip etmiştir. Türkiye, Çin'in, kuruluşundan 22 yıl sonra, 5 Ağustos 1971 y1lında resmen tanımıștır (Türkiye Cumhuriyeti Pekin Büyükelçiliği Bilgi Notu, 2008). 1970’li yıllarda iki ülke arasında çok düşük bir ilişki düzeyi mevcutken, 1980'li yıllar boyunca Türkiye-Çin ilişkilerinde bir canlanma görülmüştür. 1991'de Sovyetler Birliğìnin dağılması sonrasında Ankara’nın izlediği Orta Asya politikası Pekin'i endişelendirmiştir. 2000'li yıllarla birlikte ise üst düzey ziyaretlerin arttığı görülmektedir (Çolakoğlu, 2012, s. 54).

Türkiye ve Çin Halk Cumhuriyeti arasındaki ekonomik ve ticari ilişkiler de son yıllarda gelişmektedir. 1990 yılında 238 milyon ABD Doları olan ikili ticaret hacmi 2007 y1lında 14,2 milyar ABD Doları seviyesine ulaşmıştır (Türkiye Cumhuriyeti Pekin Büyükelçiliği Bilgi Notu, 2008). Türkiye ile Çin arasındaki dış ticaret hacmi 2012 yılı itibari ile 24 milyar doları aşmıştır (Kızılca, 2014). 2005-2010 yılları arasında Çin ile Türkiye arasındaki ikili ticaret büyüme oranı
25.3\% olmuştur. Çin'in başlica ticaret ortakları arasında Türkiye 35. sıradadır (Ankara Strateji Enstitüsü Türkiye-Çin İlişkileri Raporu, 2012, s. 10).

Cumhurbaşkanı Yardımcısı Xi Jinping Şubat 2012'deki Türkiye ziyareti sırasında iki ülke arasında nükleer enerji ve demiryolları başta olmak üzere büyük projeler gündeme gelmiştir. Türkiye bu alanda hızlı tren projeleri de dâhil olmak üzere Çinli firmalarla yaklaşık 5.000 km’lik bir demiryolu ağı döşetmeyi planlamaktadır. Son 20 yıldır söylenen ancak bir türlü hayata geçirilemeyen "Çağdaş İpekyolu" projesi de Türkiye’nin Çin, Kafkasya ve Orta Asya ülkeleriyle ticareti açısından son derece önemlidir (Çolakoğlu, 2012, s. 61).

\section{Türkiye'de Çin Medyası}

Çin ile Türkiye arasında gelişen ekonomik ve siyasi ilişkilere rağmen, Çin'in Türkiye kamuoyundaki alg1sı ağırlıklı olarak olumsuzdur. Çin’in diğer ülkelerin kamuoylarında nasıl algılandığına ilişkin yapılan çalışmalar, Çin'le ilgili algının dalgılı bir seyir izlediğini ortaya koymaktadır. BBC Dünya Servisi Türkiye’nin de aralarında bulunduğu 21 ülkede Çin'in nasıl alg1landığını ölçmek amacıyla bir araştırma yapmıştır. 2008 ila 2009 yıllarının karşılaştırıldığı araştırmaya göre, Türkiye Çin’e yönelik olumsuz algının en yüksek olduğu ülkelerden biridir (BBC World Service Poll 2009, Aktaran: Fook, 2010, s. 549-551). Pew Research Center Survey'in yaptığı araştırmaya göre ise 2005-2010 yılları arasında ABD, Pakistan, Brezilya, Arjantin, Ürdün, Polonya, Kenya ve Nijarya'da Çin'e yönelik pozitif algıda bir artış söz konusudur. 2005 yılıyla karşılaştıııldığında 2010 yılında Türkiye, İngiltere, Fransa, Almanya, İspanya, Lübnan, Misır, Meksika, Japonya, Güney Kore, Endonezya ve Hindistan'da Çin ile ilgili negatif algının arttığı görülmektedir. Aynı yıllar arasında Rusya kamuoyundaki Çin algıs1 ise değişmemiştir (Pew Global Attitudes Project 2009, Aktaran: Fook, 2010, s. 551). Türkiye Çin ile ilgili olumsuz görüşlerin en fazla düştügü ülkelerden biridir. Türkiye kamuoyundaki görüşlerin değişiminin yüzde olarak görünümü Tablo l'deki gibidir.

Tablo 1. Çin Hakkında Olumlu ya da Olumsuz Bir Görüşünüz Var Mı?

\begin{tabular}{|c|c|c|c|c|c|c|c|}
\hline Yıl & 2005 & 2006 & 2007 & 2008 & 2009 & 2010 & 2005-2010 yılları arasındaki değişim \\
\hline Yüzde-\% & 40 & 33 & 25 & 24 & 16 & 20 & -20 \\
\hline
\end{tabular}


Tabloda da görüldüğü gibi 2005 yılında yüzde 40 olan olumlu görüş, 2009 yllına kadar düzenli olarak azalmıştır. Beş ylllık süreçte, olumlu görüşün en düşük olduğu yılın Sincan-Uygur Özerk Bölgesinde olayların yaşandığ 2009 yılı olması dikkat çekicidir. 2010 yılında 2009 yılına göre bir artış olduğu görülmektedir. Çin'in, söz konusu araştırmaların da ortaya koyduğu olumsuz algıyı ortan kaldırabilmek için, diğer ülkelerde olduğu gibi, Türkiye'de de yumuşak güç kaynaklarını daha etkili bir biçimde kullanmaya çalıştığı görülmektedir. Türkiye ile ilişkilerin geliştirilmesi amacıyla kullanılan yumuşak güç araçlarının başında hiç kuşkusuz medya gelmektedir. Çin, özellikle son beş yllda Türkiyede televizyon, radyo, dergi gibi geleneksel medyanın yanında yeni medyayı da yoğun bir biçimde kullanmaktadır. Türkiye'deki medya yapılanması, Çin'in 2001 yılında açıladığı medyada “dışa açılma” stratejisiyle uyumludur. Çin'den yapılan yayınlarla başlayan süreç, Türkiyedeki radyo ve dergi gruplarıyla yapılan yayın anlaşmalarıyla devam etmiş, son olarak Çin kendi televizyonunu, internet sitelerini hayata geçirmiş, radyo kurma çalışmalarını sürdürmektedir.

Çin’in Türkiye ile ilişkilerinde medyayı kullanmas1 yeni değildir; Çin Uluslararası Radyosu Türkçe Servisinnin kurulmasıyla başlamıştır. Yayın hayatına 21 Ekim 1957'de başlayan Çin Uluslararası Radyosu Türkçe Servisi, başta Türkiye Cumhuriyeti olmak üzere tüm dünyada Türkçe konuşan insanlara hitap eden bir yayın anlayışıyla yola çıkmıştır. Yayınlar, ilk yıllarda günde iki kez yarımşar saat yapılmıştır. Haberler, Uygurların toplu halde yaşadığı Xinjiang (Sincan) bölgesine özgü müzik ve klasik Türk müziğinden oluşan yayınlara, zamanla haber-yorum ve Çin`i tanıtan programlar da eklenmiştir (http://turkish.cri. cn/1/2007/05/22/1@71929.htm). O zamanki adiyla Pekin Radyosu olan Çin Uluslararası Radyosu Türkçe Servisinde yayınlar, Sovyet Sosyalist Cumhuriyetler
Birliğinden gelenler tarafından gerçekleştirilmiştir. Çin ve SSCB arasında yaşanan gerilim nedeniyle söz konusu kişilerin ülkelerine dönmesinin ardından dönemin Çin Başbakanı Zhou Enlai'nin talimatıyla yerli radyocuların yetiştirilmesine ağırlık verilmiştir (Köfteoğlu, 2013-2014, s. 32). Uygur kökenli bir öğrenci olan Rukiye Hacı, Türkçe spikerlik eğitimi alan ilk Çin vatandaşı olmuştur. Bunu izleyen yıllarda Türkçe eğitimini tamamlayıp Pekin Radyosu'nda çalışmaya başlayan Çinli sayısı giderek artmıştır (http://turkish. cri.cn/1/2007/05/22/1@71929.htm). İlk yllarda en büyük sorun, kaynakların yetersiz olması nedeniyle Türkçe öğrenme konusunda yaşanmıştır (Köfteoğlu, 2013-2014, s. 33).

Çin ve Türkiye arasında 1971 'de diplomatik ilişkilerin kurulması ve özellikle Çin'de 1978'de reform ve dışa açılma uygulamalarının başlatılmasıyla birlikte, Çin ve Türk halkları arasındaki karşılıklı anlayışı artırmak ve dostluğu geliştirmekle görevlendirilen Pekin Radyosu Türkçe Servisi, hızlı bir gelişme dönemine girmiştir. Servisin yayıncı kadrosu giderek genişlemiş, yayınların hem şekli, hem de içeriğinde önemli değişimler yaşanmıştır. Türkçe Servisinnin yayınlarında, Çin'in her yönünü kapsayan programlar ve önemli olaylarla ilgili özel yayınlar düzenli olarak yer almaya başlamıştır. Çin ve Türkiye arasında 1980'li yıllarda hız kazanan siyasi, ekonomik, ticari ve kültürel değişimlerle birlikte, iki ülke arasında devlet liderleri başta olmak üzere, yoğun karşılıklı ziyaretler gerçekleştirilmiştir. Bu dönemde özellikle Pekin Radyosu Türkçe Servisi çok sayıda program hazırlamış, röportajlar yapmıştır (http://turkish.cri. cn/1/2007/05/22/1@71929.htm).

CRI Türkçe Servisi Müdürü Xia Yongmin’in verdiği bilgiye göre günümüzde serviste 5’i Türk olmak üzere toplam 18 kişi çalışmaktadır (Köfteoğlu, 2013-2014, s. 32). Başlangıçta günde $2 \mathrm{kez}$ yarım saat Türkçe

Tablo 2. CRI Türkçe Yayın Çizelgesi

\begin{tabular}{|c|c|c|c|}
\hline Türkiye Yaz Saati & Türkiye Kış Saati & Dalga & KHZ \\
\hline $18.00-19.00$ & $17.00-18.00$ & Kısa dalga & $7230 / 9565$ \\
\hline $19.00-20.00$ & $18.00-19.00$ & Kisa dalga & $6165 / 7180$ \\
\hline $22.00-23.00$ & $21.00-22.00$ & Kısa dalga & $7255 / 9655$ \\
\hline $22.30-23.00$ & $21.30-22.00$ & Kısa dalga & 7165 \\
\hline $22.30-23.00$ & $21.30-22.00$ & Orta dalga & 1170 \\
\hline
\end{tabular}


programlara yer verilirken, Türkçe yayınların süresi de 2004'te bir saate ve günde dört tekrara çıkarılmıştır (Çin Radyosu'nun Türkçe Servisi 50. Yaşını Kutlad1, http://turkish.cri.cn/281/2007/10/30/1@82514. $\mathrm{htm})$. Çin Uluslararası Radyosu Türkçe Servisinnin günümüzdeki yayın çizelgesi ise Tablo 2'deki gibidir (http://turkish.cri.cn/862/2009/03/27/141s112505. htm).

Her gün birer saat süren ve dört kez tekrarlanan Türkçe yayınlarında 15 dakikalık haber bülteni ve 10 dakikalık haber yorumundan sonra çeşitli konulardan programlar yer almaktadır: Radyoda pazartesi günleri Kültür Dünyasından, Çin Mutfağı ve Çince Öğreniyoruz salı günleri Ekonomi Yaşamı, Spor Dünyası, Öykülerle Beş Dakika, Dinleyici Postası ve Çince Öğreniyoruz; çarşamba günleri Dünü ve Bugünü ile Xinjiang, Kadın Kadına, Bilim ve Sağlık ve Çince Öğreniyoruz"; perşembe günleri Toplumsal Yaşam, Bir Yabancı Gözüyle Çin, Bir Çinli Gözüyle Dünya, Çin'deki Dünya Mirasları, ve Çince Öğreniyoruz; cuma günleri Çin'de Yolculuk, Bejing'i Taniyalım, Çin'deki Azınlık Milliyetler, Dinleyici Postası ve Çince Öğreniyoruz adlı programlar yayınlanmaktadır (Köfteoğlu, 2013-2014, s. 33).Çin Uluslararası Radyosu Pekin'den yaptığı yayınlarla yetinmemiş 1991'de Ankara'da temsilcilik açmıştır. Temsilciliğin ilk yöneticisi Prof. Lu Jingming olmuştur (Köfteoğlu, 20132014, s. 33). Bugün radyonun İstanbul ve Ankara’da temsilcileri bulunmaktadır.

Radyo yayınlarına çok önem veren Çin, Türkiye'deki radyolarla yaptığ 1 yayın anlaşmalarıyla da dinleyicilere ulaşmaya çalışmaktadır. Bu anlaşmalardan ilki Sincan-Uygur Halk Radyosu (XJBS) ile İstanbul merkezli bir radyo olan Yön Radyo arasında 2007 yılında yapılmıştır. Anlaşma kapsamında Yön Radyo SincanUygur'dan Merhaba adlı programı her gün bir saat olarak yayınlamaya başlamıştır. Programda Çin ve Sincan-Uygur Özerk Bölgesinden haberler, kültür ve Uygur Türküleri yer almaktadır (http://www.yonradyo.com.tr/index.php/yazi/urumciden-istanbula-dinleyici-koprusu). Benzer bin anlaşma Çin Uluslararası Radyosu (CRI) ile Yön Radyo arasında 2010 yilında imzalanmıştır. Yön Radyo Genel Yayın Yönetmeni Er-

1 Yön Radyo, Yönelim Yayıncılık Sanayi ve Ticaret A.Ş bünyesinde 2003 yılında yayın hayatına başlamıștır. Bölgesel yayın lisansı bulunan radyo İstanbul ve çevresine FM band1 96.6'dan yayın yapmaktadır. Ağırlıklı olarak türkü yayınlayan radyo, Türksat uydusu, internet (www.yonradyo.com.tr) ve cep telefonları üzerinden de dinleyicilerine ulaşmaktadır. dal Emre ile yaptığımız söyleşide edindiğimiz bilgiye göre, bu anlaşma çerçevesinde Yön Radyo Çin'den Merhaba adlı programı haftada yedi gün ve günde beş periyot yayınlamaya başlamıştır (Erdal Emre ile söyleşi, 2015). Bugün ise yayınlar üç periyot (12:30, 17:30, 20:00- ilk iki yayın periyodu yarımşar saat, son periyot ise bir saat) halinde yayınlanmaktadır. Çin Uluslararası Radyosu Türkçe Servisìnin hazırladığı programda Çin'den haberlerin yanı sıra kültür-sanat, ekonomi, turizm bölümleri yer almaktadır. Programda ayrıca Çince öğrenmek isteyenler için bir bölüm bulunmaktadır (http://www.yonradyo.com.tr/index. php/program/cinden-merhaba). Yön Radyo ile yapılan anlaşma kapsamında aynı programlar, aynı saatte Ankara’daki Radyo Özgür'den ${ }^{2}$ yayınlanmaktadır (Erdal Emre ile söyleşi, 2015). Yön Radyo ile yayın işbirliği söz konusu programlarla da sınırlı değildir; zaman zaman özel yayınlar yapılmaktadır. Temmuz 2009 'da Urimçe'de yaşanan olaylarla ilgili Urumçiden Son $\mathrm{Ha}$ berler, 1 Ekim 2009'da Çin Halk Cumhuriyeti’nin kuruluşunun 60 . Yıldönümünün kutlama töreni; 1 Eylül 2010'da Xinjiang'daki toplumsal ve ekonomik gelişmeleri tanitmak amaciyla yapilan Tanri Dağı̀ndan Gelen Ses söz konusu özel programlara örnek gösterilebilir (Erdal Emre ile söyleşi, 2015).

Çin'in Türkiye'deki radyolarla yaptığı işbirliği anlaşmalarından bir diğeri ise, İstanbul merkezli bir radyo olan Radyo Mega $a^{3}$ yla yaptığı anlaşmadır. Çin medya organizasyonu Gb Times Medya 2013 yllında Türkiye'de ofis açarak faaliyetlerine başlamıştır. Avrupa, Asya, Afrika kitasinda toplam 14 ülkede medya alanında faaliyetlerini sürdüren GB Times'ın Türkiyedeki ilk medya yatırımı ulusal çapta yayın yapan Radyo Mega ile olmuştur (http://www.gazeteciler.com/gundem/gbtimes-turkiyede-faaliyetebasladi-62000h.html). Global Times Türkiye Genel Müdürlügün'ne getirilen Radyo programcısı ve akademisyen Michael Kuyucu, Radyo Mega'nın Çin'in Türkiye'de tanıtılması ve iki ülke arasındaki kültür alanındaki İpek Yolu’nun kurulması için çaba

2 Radyo Özgür, Ankara ve çevresine FM bandı 108.0 frekansından ulaşmaktadır. Radyonun ayrıca internet üzerinden (www. radyoozgur.com.tr) yayını bulunmaktadır.

3 Türkiye’nin ilk özel radyo kanallarından biri olan Radyo Mega 1994'da kurulmuştur. Ulusal yayın lisansı bulunan radyo İstanbul (105.4) İzmir (99. 7), Ankara (102. 6) başta olmak üzere bir çok ilde FM bandı üzerinden, ayrıca Türksat uydusu ve internet üzerinden (http://www.radyomega.fm) yayın yapmaktadır. Merkezi İstanbul'da bulunan radyo popüler Türkçe şarkılar yayınlamaktadır. 
harcayacağını söylemiştir (http://www.gazeteciler. $\mathrm{com} /$ gundem/gbtimes-turkiyede-faaliyete-basladi62000h.html). CRI Türkçe Servisinin müdürü Xia Yongmin'in verdiği bilgiye göre, Türkiye’nin ilk özel radyo kanallarından biri olan Radyo Mega'yla yapılan işbirliği anlaşması Yön Radyo ile yapılan anlaşmadan farklıdır. Radyo Mega, Çin Uluslararası Radyosu Türkçe Servisi’nden aldığı programları Türkiye’ye uyarlayıp dinleyicilerine aktarmaktadır (Köfteoğlu, 2013-2014, s. 32).

Uzakdoğu'dan Esintiler, Çin'de Yaşam, Asya Mutfa$\breve{g} 1$ gibi programlarda, dinleyicilere Çin dili, kültürü, ekonomisi, ve tarihi hakkında bilgiler verilmektedir. Yön Radyo'daki kuşak programlardan farklı olarak Radyo Mega'daki programlar tüm güne yayılmıştır. Programlarda yer verilen Türkçe şarkıların ardından Çin'le ilgili yirmi-otuz saniye süren bilgiler yayınlanmaktadır. Programların sonunda "dinlediğiniz program GB Times tarafından hazırlanmıştır” ifadesi yer almaktadır. Haber bültenlerinde ise Çin gündeminden haberlerin yanı sıra dünya ve Türkiye gündeminden haberler yayınlanmaktadır. 21-28 Mayıs tarihleri arasında Radyo Mega'da yer verilen haberleri dinleyerek yaptığımız incelemeye göre, bültenlerde ağırlıklı olarak yer alan haber konuları şu başlıklar altında toplanabilir:

Radyo Mega'da, Çinli devlet yetkililerinin uluslararası konularla ilgili yaptıkları açılamalar ve diğer ülkelerin devlet yetkilileriyle yaptıkları görüşmeler geniş yer ayrılmaktadır: Çin Dışişleri Bakanlığı Sözcüsü Hong Lei, "ABD, Güney Çin Denizi konusunda tarafsız kalmalı" dedi-27.05.2015; Çin Dışişleri Bakanlığı Sözcüsü Hua Chunying "ABD, kışkırtıcı eylemlerini durdurmalı" dedi-27.05.2015; Çin Başbakanı Li Keqiang "İspanya ile iş birliği potansiyelimiz büyük" dedi27.05.2015; Çin Cumhurbaşkanı Xi jinping "Eğitimin bilişim teknolojileri hızlandırılmalı" dedi-26.05.2015; Çin hükümeti, Kosova sorununun diyalog yoluyla çözülmesi gerektiğini vurguladı-26.05.2015; Çin Başbakanı Li Keqiang, Şili Devlet Başkanı Michelle Bachelet ile Santiago da bir araya geldi-26.05.2015; Çin Başbakanı Li Keqiang, Bogotá da Kolombiya Devlet Başkanı Juan Manuel Santos ile bir araya geldi-26.05.2015.

Çin'in ekonomik gelişimini, turizm potansiyelini, bilimsel çalışmalarını öne çıkaran haber bültenlerinde önemli bir yer tutmaktadır: Çin yenilenebilir enerji alanında öncü rol oynuyor-26.05.2015; Çin'in hidroelektrik jeneratör kapasitesi 300 milyon kilovatı aşt1-25.05.2015, Çin Hükümeti, 2017 sonuna kadar internet ve teknoloji odaklı girişimlere 500 milyar yuan (182 milyar dolar) yatırım yapmayı planliyor-21.05.2015; İpek Yolu İnternet Konferans1 Xi`an>da yapıldı-26.05.2015, Çin, küresel turizm anketinde 17. sıraya yükseldi-27.05.2015; Dünya Sağlık Örgütü, Çin'in geliştirdiği ebola testini tavsiye ediyor-21.05.2015.

Radyo Mega'da, Çin Ordusunun faaliyetleriyle ilgili haberlere sık sık yer verilmektedir: Çin ve Rusya ortak deniz tatbikatı gerçekleştirdi-22.05.2015; Devlet Konseyi Bilgilendirme Ofisi Çin>in askeri stratejisi üzerine beyaz kitap yayınladı-27.05.2015, Çin Devlet Konseyi Enformasyon İdaresi tarafından yayımlanan "Çin'in Askeri Stratejisi" başlıklı "beyaz belge"de, Çin donanmasının artık kendi karasularını savunmadan çok "açık denizleri korumaya", hava kuvvetlerinin de "taarruz ve daha güçlü hava sahası savunmasına" yöneleceği belirtildi-28.05.2015.

Çin'in yaptığı dış yardımlar: Çin, Nepalıe 80 milyon yuan değerinde yardım malzemesi gönderdi-21.05.2015; Çin, Kamboçya ya ağır silah yardımı yapt1-26.05.2015.

Türkiye-Çin ilişkileriyle ilgili haberler: Türkiye geçen yıl Çin'den yaklaşık 39 milyon dolarlık bebek arabası ithal etti-25.05.2015; Çin deniz filosu beş gün İstanbul'da olacak-26.05.2015.

Radyonun haber bültenlerinde ayrica Türkiye ve dünya gündeminden haberlere yer verilmektedir.

Haberler bültenlerinin sonunda "Radyo Mega $\mathrm{Ha}$ ber Merkezi tarafindan hazırlanan haber bültenini dinlediniz" ifadesi yer almaktadır. Radyo Mega'da yayınlanan haberlere GB Times'in facebook sayfasinda (https://www.facebook.com/gbtimesturkey?filter=1) da, başlıklar halinde yer verilmektedir.

Çin, Türkiye'de yapılan radyo yayınlarının etkisini ölçmek amacıyla çeşitli çalışmalar yapmaktadır. Yön Radyo Yönetim Kurulu başkanı Yüksel Mansur Kılınç'ın, 05.04.2015 tarihinde yaptığımız söyleşide verdiği bilgiye göre, Çin Uluslararası Radyosu bu amaçla Türkiye'deki radyo dinleyicilerinin telefonla katıldığı bir program gerçekleştirmiş, Sincan Halk Radyosu yöneticileri ise İstanbul'da düzenlenen bir 
etkinlikte radyo dinleyicileriyle bir araya gelmiştir. Kılınç’in verdiği bilgiye göre, Çinli yetkililer Türkiye’de yapılan radyo yayınları sayesinde ülkelerinin tanınırlığının arttığı yönünde tespitlerde bulunmuştur. Çin, bu tespitlerin sşığında FM bandından yayın yapacak bir radyoyu (Çin Halk Radyosu) hayata geçirmek için hazırlıklarını sürdürmektedir (Yüksel Mansur Kılınç ile söyleşi, 2015).

GB Times Türkiye ile Media Times tarafından Türkiye'de kurulan medya platformu, Çin'in Türkiye'de yaptığı yayın faaliyetleri açısından dönüm noktalarından biridir. 23 Ekim 2014 yapilan basin toplantısinda duyurulan platformda CTV televizyonu ve YouTube kanalları, İnteraktif Çince Öğretim ve İletişim Portal,, China Browser, Merhaba Çin mobil uygulaması, İpek Yolu sitesi ve Digichina OTT bulunmaktadır ("Çin, Türkiyeye Artık Bir “tık” Kadar Yakın”, http://turkish. china.com/news/china/543/20141023/190506.html).

CCTV News ile D-Smart ve Teledünya platformu üzerinden Türkiye'deki izleyicilere ulaşmakta olan Çin'in, CTV televizyonunu yayına sokması Türkiye'yeki medya faaliyetlerine verdiği önemin bir göstergesidir. CTV televizyonunu CCTV News'ten farklı kılan ise yayınlarını Türkçe (altyazılı) yapıyor olmasıdır. CTV, Türksat $4 \mathrm{~A}$ uydusu ve internet üzerinden (http://garantisistem.com/FMP/C_TV/) izleyicilere ulaşmaktadır. CTV yayınlarında belgeseller (Çin'de Maddi Olmayan Kültür Mirasları, Değerli Ağaçlar: Hongmu, Sun Bin Dövüşü, Çin Tibbr v.b.), kültür-sanat ve turizm programları (Ay Takvimi v.b.) televizyon dizileri (Zarif Anneler, Değerli Hayat, Güzel Hayat, Bir Tava Hayal v.b.) ve filmlerin yanı sıra Türk ve Çinli sanatçıların müzik kliplerine yer vermektedir. CTV'de yayınlanan diziler arasında tür olarak gençlik dizileri ağırlıktadır. Bu dizilerde batılı hayat-giyim tarzının, modern şehirlerin-mekanların ön planda olması dikkat çekicidir.

CTV'de yayınlanan program ve dizilerin videolarina ttps://www.youtube.com/user/chinatvturkish adresinden ulaşılabilmekte, kanalın ayrıca facebook sayfasi (https://www.facebook.com/pages/CTVT\%C3\%BCrkiye/1479978998952442) bulunmaktadır.

Çin'in Türkiye'deki televizyon yayıncıllğğ çalışmaları $C T V$ ile sınırlı değildir. Çin'in Türkiye’nin devlet televizyonu TRT ve resmi haber ajansı Anadolu Ajansı ile haber ve temalı programlar yapma konusunda bir işbirliği anlaşması bulunmaktadır (Köfteoğlu, 20132014, s. 32).
Çin'in Türkiyede yazılı medya (gazete, dergi) alanında yaptığ 1 ilk girişim haftalık Beijing Review ile aylık China Today ve China Pictorial dergilerinin İngilizce baskılarının satılmaya başlanması olmuştur. Üç derginin Türkiye'de satışı, Doğan-Burda Dergi Grubu ve Türk-Çin İktisadi Eşleştirme Merkezi-TUCEM’in işbirliği ile 2007 yılının Haziran ayında başlamıştır (http://www.hurriyet.com.tr/ekonomi/6904347. asp?gid=196). 2010'un sonlarında ise China Today Türkiye (tamamı Türkçe) yayın hayatına başlamıştır. China Today Türkiye, diğer ülkelerdeki versiyonlardan farklı olarak yalnızca China Today'den değil, China Pictoral ve Beijing Review gibi dergilerden de yazı ve fotoğraf desteği almıştır. Ağırlıklı olarak orijinal versiyondan yapılan çevirilerden oluşan dergide Türkiye'de hazırlanan güncel haber ve yorumlara da yer verilmekteydi. Ancak çeşitli sorunlar nedeniyle dergi yedi sayı çıkabilmiştir (Aslan, 2011).

27 Eylül 2012 tarihinde, Çin Büyükelçisi Gong Xiaosheng ve Çalık Holding Yönetim Kurulu Başkanı Ahmet Çalık'ın katılımıyla, China Today'in Turkuvaz Medya bünyesinde yayınlanması için anlaşma imzalanmıș (http://www.sabah.com.tr/ekono$\mathrm{mi} / 2012 / 09 / 27 /$ cinin-prestijli-dergisi-turkiyede), dergi Türkiye'deki ikinci serüvenine başlamıştır. Derginin Turkuvaz Medya bünyesinde hazırlanan ilk sayısı 2012'nin Ekim ayında yayınlanmıştır. Diğer dillerde ayda bir yayınlanan dergi Türkiye'de 2 ayda 1 sayı (Yılda 6 Sayı) olarak hazırlanmaktadır.

Çalışmada derginin 1,4, 8, 12 ve 16. sayılarını örneklem alarak, yumuşak güç kavramı çerçevesinde incelendi. İncelemede, dergide beş başlık altında toplanabilecek haber, yorum ve analizlerin öne çıkarıldığı saptandi:

Çin-Türkiye ilişkilerini ele alan haber, yorum ve analizler dergide ağırlıklı bir yer tutmaktadır. Haber, yorum ve analizlerde Türk yatırımcılar Çin'le ticaret ve yatırım yapmaya davet edilmektedir. Dergide, Çine yapılacak yatırımlar ve ticaretle ilgili yol haritası da sunulmaktadır: "Çin'i Keşfetme Zamanı: Dünyanın Yükselen Değeri Çin, Küçük Büyük Bütün Girişimciler İçin Çok Büyük Bir Pasta Sunuyor" (Uçar, 2012, s. 12-18), "Kobiler İçin Büyük Pazar" (Çıplak, 2012, s. 19), "Çin-Türkiye Stratejik İşbirliği İlişkisinin Gelişiminin Derinleşmesini Hızlandıralım” (Xiaosheng, 2012, s. 20-21), "Türk Girişimcilere Birçok Fırsat Var" (Köfteoğlu, 2012, s. 24-27), "Çinlilerle Ortaklık İçin En Doğru Zaman” (Uçar, 2013, s. 14-19), "Her Ka- 
pıyı Açan Türkler: Çin'den İthalat Yapan, Mal Satan ya da Bu Ülkede İş Kuran Türk Bilgelerle Mutlaka Tanışın" (Uçar, 2013-2014, s. 12-19), "Dostluğu Pekiştiren Fuar” (Köfteoğlu, 2013-2014b, s. 24-25), “533 Kilometre Bitiyor: Ankara-İstanbul Hızlı Tren Hattı 533 Kilometre Uzunluğunda ve İnşası Üç Etapta Tamamlanacak" (Wandi, 2013-2014, s. 28-29), "Güneş Devi'nin Türkiye Macerası” (Kızlocak, 2013-2014, s. 34-35), "Bulutların Üzerindeki İpekyolu" (Limin, 2013-2014, s. 26-27), "Mobilya Pazarında Potansiyel Büyük" (Shujun, 2014, s. 18-19), "Şimdi İş Yapma Zamanı" (Köfteoğlu, 2014, s. 34-35), "Çin'de Kozmetik Mağazaları Açıyor” (Çıplak, 2015a, s. 32-33), "İstanbul'da Çince Öğretecek" (Çıplak, 2015b, s. 3436).

Çin ekonomisini öne çıkaran haber, yorum ve analizler de dergide geniş yer tutmaktadır. Dergide, Çin'in ekonomik gelişiminin dünya ekonomisi için öneminin altı özellikli çizilmektedir: "Dünyanın Bir Çin Rüyasına İhtiyacı Var" (Jianmin, 2013, s. 40-41), "Çinli Firmalar Enerjinin Yükselen Değeri Oldu, Yatırım, Tüketim ve Mevcut Ekonomik Durum" (Lin, 20132014, s. 36-39), "Ekonomik Büyümede İstikrarlı Toparlanma" (Shujun, 2013-2014, s. 20-22), "Komşuları da Kazançlı” (Anbo, Qian, 2014, s. 30-33), “2015’in Kalkınma Hedefleri Belirlendi” (Wandi, 2015, s. 6), Dünyanın Fabrikası'ndan Dünya’nın Yatırımcısına" (Xiaoyan, 2015, s. 12-16), "Ekonomik Canlılı̆̆1 Teşvik Dönemi” (Ruili, 2015, s. 37-39), "Avrupa, En Büyük Yuan Pazarı Olma Yolunda”, (Monan, 2015, s. 59).

Dergide başta Sincan-Uygur Özerk Bölgesi'yle ilgili olmak üzere, Çin'deki özerk bölgelerle ilgili politikasına da yer verilmektedir. Söz konusu haber, yorum ve analizlerde Çin'in çok kültürlülüğe verdiği önem ve etnik ayrım yapmadan her bölgeye yatım yaptığ vurgusu dikkat çekicidir: "Ulusal Sincan Zhundong Ekonomik ve Teknolojik Kalkınma Bölgesi” (Xiaodong ve Zhongming, 2013-2014, s. 72-73), "10 Yılda Gerçekleşen Mucize: Uangxi Zhuang Özerk Bölgesi"(Ying, 2013, s. 80-82), "Tam Gaz Sincan'a" (Fangfang, 2014, s. 56-59).

Çin'in dış politikasıyla ilgili haber, yorum ve analizlerde Afrika ülkeleriyle ilişkiler önemli bir yer tutmaktadır. Haberlerde Çin'in Afrika ülkelerindeki yatırımlarının altı çizilmekte, siyasi ilişkiler de değinilmektedir: "Afrika’nın Çin Rüyası" (China Today Türkiye, 2013- 2014, s. 58-59), "Afrika'da Yatırımlar Artıyor” (Jirong, 2013-2014, s. 60-61), “İsviçre ile İliş- kiler Yeni Zirvelere Taşınıyor” (Song, 2014, s. 28-29), Geleceği İzlemek: Çin-Yunanistan" (Lintao, 2014, s. 60-63), Etiopya'daki Çin Şirketleri” (Jun, 2015, s. 4648), "Çin-İtalya Köprüsü” (Chengzi, 2015, s. 56-58).

Dergide en fazla rastlanan diğer iki konu ise Çin turizmi ve Çin kültürü-tarihiyle ilgili haber, yorum ve analizlerdir: "Çay Köylerine Turlar Revaçta" (Xueying, 2012a, s. 44-47), "Çin'in 10 Gözde Sahil Şehri” (Xuyeing, 2012b, s. 72-75), "Harbin: Kuzeydoğu Çin'in Buzdan Periler Diyarı" (Wingyu, Lindan, Xaoyan, 2013, s. 76-79), "Gök Kubbenin Altı" (Xıaofei, 2013-2014, s. 64-69), "Çin'de Turizm Ateşi” (Feng, 2014, s. 24-25), "Wuzhou: Lingnan’ın Unutulmaz Şehri" (Meiling, 2014, s. 78-81), "Yuxi: İnsanlığın Atasının Evi” (Meiling, 2015, s. 66-69), "Şian: Eski Hazineleri Arayanlar İçin Biçilmiş Kaftan" (Shujun, 2015, s. 70-73). "Tarımsal Miraslar" (Hong, Menzel, 2012, s. 54-57), "Lu Yaozu, Geleneksel Çin Mimarisini Dünyaya Taşıyor” (Jio Feng, 2013, s. 74-75), Zunyi Efsanesi (Meiling, 2013-2014, s. 74-81), “Tian Jiaxin Çin'i Dünyaya Müzikle Tanıtıyor" (Wang Wenjie, 2014, s. 64-67), "Dünden Bügüne Çin Çalgıları”, (HuiYuan, 2015, s. 78-82).

Çin geleneksel medyanın yanında yeni medyayı da kullanmaktadır. Çin Uluslararası Radyosu'nun internet sitesi bu alanda ön plana çıkmaktadır. Radyonun, "http://turkish.cri.cn" adresindeki Türkçe internet sitesi Aralık 2003ıte yayın hayatına başlamıştır (http:// turkish.cri.cn). CRI Türkçe Servisi Müdürü Xia Yongmin’e göre sitenin aylık ortalama ziyaretçi sayısı 40 bine ulaşmıştır (Köfteoğlu, Aralık 2013-Ocak 2014, s. 32). Sitede Haber ve Gündem, Kültür ve Yaşam, Çin-Türkiye İletişimi, Turizm, Çince Öğretimi, Xinjiang (Sincan), 56 Etnik Grup, Çin Ansiklopedisi, Ekonomi Gündemi, Çin Müziği gibi bölümler bulunmaktadır (Bkz. http://turkish.cri.cn).

21-28 Mayis 2015 tarihleri arasinda, "http://turkish. cri.cn" internet sayfasında yaptığımız incelemeye göre, bültenlerde ağırlıklı olarak yer alan haberler şu başlıklar altında toplanabilir:

İnternet sitesinde, Çinli devlet yetkililerinin uluslararası konularla ilgili yaptıkları açıklamalar ve Çinli devlet yetkililerinin diğer ülkelerin devlet yetkilileriyle yaptıkları görüşmeler geniş yer tutmaktadır. Çinli devlet yetkililerinin açıklamaları arasında ABD aleyhtarı olanların sayısının fazlalığı dikkat çekicidir. Diğer ülkelerle ilgili açıklamalarda ise, Çin’in yumu- 
şak güç politikası paralelinde, dostluk mesajları verilmektedir: Çin: ABD, Güney Çin Denizi konusunda tarafsız kalmali-21.05.2015), Jiechi BRICS toplantısına katılacak-21.05.2015, Çin: Endonezya, tekne sorununu açıklığa kavuşturmalı-21.05.2015, Li Keqiang Kolombiya Devlet Başkanı'yla görüştü-22.05.2015, Çin liderlerinden Kolombiyaya taziye mesaj1-21.05.2015, Çin Başbakanı Kolombiyada-22.05.2015, Li Keqiang ve Juan Manuel Santos ortak basin toplantisı düzenledi-22.05.2015, Çin'den Güney Sudan'da uzlaşma çağrısı-22.05.2015, Li Keqiang Peru'ya geçti-23.05.2015, Li Keqiang Peru Devlet Başkani’yla görüştü-23.05.2015, Li Keqiang ve Peru Cumhurbaşkanı basın toplantısında-23.05.2015, Li Keqiang: "ABD, egemenlik hakkı konusunda sorumsuzca yorum yapmamalı-22.05.2015, ABD Irak'ı silahlandır1yor-22.05.2015, Li, Çin-Latin Amerika "Kültürel Değişim Semineri”ne katıldı-24.05.2015, Li Keqiang'in Latin Amerika gezisi dikkat çekti-25.05.2015, Xi Jinping'den Liberya Devlet Başkanı'na Ebola tebriği-25.05.2015, Çin'den ABD'ye Güney Çin Denizi tepkisi-25.05.2015, Çin'den Suudi Arabistan'daki intihar saldırısına kınama-25.05.2015, Li: Latin Amerika ve Karayip ülkeleriyle dostluğu pekiştireceğiz-26.05.2015, Çin ve Şili işbirliğini güçlendirmek için kolları sıvadı-26.05.2015, Çin-Şili işbirliğinde potansiyel büyük-25.05.2015, Çin-ASEAN istişaresi sürüyor, $A B D$ müdahil olmamal1-25.05.2015, Çin: Kosova sorunu diyalog yoluyla çözülmeli-27.05.2015, Li Keqiang ve Bacheletıten ortak basin toplant1s1-26.05.2015, Çin: Egemenliğimize aykırı eylemlere izin vermeyeceğiz-27.05.2015, Çin: ABD'den kışkırtıcı eylemleri durdurmasinı bekliyoruz-27.05.2015, Çin'den ABD'ye tepki: Tehlikeli ve sorumsuz girişimler-26.05.2015, Çin: ABD’nin kınamasının arkasında başka amaç var-28.05.2015, Li: İspanyaryla işbirliği potansiyelimiz büyük-28.05.2015.

İnternet sitesinde, Çin'in ekonomik gelişimini, turizm potansiyelini, bilimsel çalışmalarını öne çıkaran haberlere geniş yer verilmektedir: Uluslararası İpek Yolu Fuarı Xiłan'da açıldı-22.05.2015, İpek Yolu İnternet Konferansi Xian'da yapild1-25.05.2015, Xi Jinping: Eğitimin bilişim teknolojileri hızlandırılmalı-23.05.2015, Çin yenilenebilir enerji alanında öncü rol oynuyor-25.05.2015, Çin'in hidroelektrik jeneratör kapasitesi 300 milyon kilovatı aştı-25.05.2015, Bir Kuşak-Bir Yol, Çin'i Avrupàya bağlıyor-27.05.2015, Çin'de turizm altın dönem- de-27.05.2015, Nazarbayev>den "İpek Yolu Ekonomik Kuşağı”na övgü-27.05.2015, İpek Yolu güzergahındaki işbirliği güçleniyor-28.05.2015, Yunanistan, Çinlilerin turizm hedef ülkesi olmak istiyor-28.05.2015, Gümrük ortaklıkları "Bir Kuşak-Bir Yol"u ilerletecek-28.05.2015, Çin'de TV, cep telefonu ve internet birleşiyor-28.05.2015, Çin'in naklen yayın teknolojisi eğitimi çok faydalı-28.05.2015.

İnternet sitesinde, Çin'in savunma politikaları ve Çin ordusunun faaliyetleriyle ilgili haberlere sık sık rastlanmaktadır. Bu haberlerde, Çin ordusunu çok güçlü olduğu, ancak aynı zamanda barışa önem veren bir ordu olduğu vurgulanmaktadır: Çin ve Rusya’nın ortak deniz tatbikatı sona erdi, Çin, yeni savunma beyaz kitabını yayımlıyor-25.05.2015, Çin deniz filosu Türkiye de-25.05.2015, Çin, aktif savunma politikasinda 1srarlı-26.05.2015, Beyaz Kitap açıklandı: Güvenlik tehditleri artıyor-26.05.2015, Çin filosu, Türkiye ziyaretini tamamladi-28.05.2015, Çin'in "mavi bereli” askerleri dünya barışına güç veriyor 28.05.2015.

Çin-Türkiye ilişkilerini ele alan haberler: Çin'den Türkiyesye hediye kitaplar-27.05.2015.

İnternet sitesinde Türkiye ve dünya gündeminden haberlere de yer verilmektedir.

Çin'in Türkçe yayınlanın bir diğer önemli internet sitesi china.com'dur. Sitede Haberler, Ekonomi, Turizm, Kültür ve Yaşam, Yerel, Çince Öğrenin, China TV, Web Radyo, Ansiklopedi başlıklı bölümler yar almaktadır. Çin-Türkiye başlıklı bölümde ise Çin-Türkiye ilişkileriyle ilgili gelişmeler aktarılmaktadır (http:// turkish.china.com/). Sitede ağırlıklı olarak Çin’i tanıtan bilgilere yer verilmekle birlikte, dünya gündeminden de haber ve analizler de bulunmaktadır.

Çin'in hayata geçirdiği bir diğer internet sitesi ise silktrek.com'dur. 2010 yılında Çin Uluslararası Radyosu bünyesindeki CRI-Online’ın Yön Radyo’yla işbirliği yaparak kurduğu site "Çin-Türkiye Kültür ve Turizm Portalı" olarak tanıtılmıştır (http://turkish.cri. cn/862/2010/05/11/141s125747.htm). 2011 yllında ise internet sitesinin Çince versiyonu hizmete girmiştir (http://www.yonradyo.com.tr/index.php/yazi/ cinde-turkiyeyi-cince-tanitan-tek-internet-sitesiacildi). Sitede Haberler, Kültür, Otel, Ticari, Turizm, Çin Hakkında, CTV gibi başlıklar yer almaktadır (http://www.silktrek.com/). 
Son olarak Sincan Uygur Bölgesinin haber ajansı Tienşen-Tanrı Dağı Türkçe yayınlarına (http:// tr.ts.cn) başlamıştır. Sitede, Yeni, Sincan, Çin, Dünya, Türkiye, Güzel Sincan, Turizm, Etnik Gruplar, Kültür ve Yaşam, Sağlık gibi konu başlıkları bulunmaktadır (http://tr.ts.cn/home/). Sitede yer alan haberlerin bir bölümü CRI'den alınmıştır. Tienşen tarafından hazırlanan haberlerde ise Türkiye kamuoyunda Sincan-Uygur Özerk Bölgesi konusundaki hassasiyetin dikkate alındığı görülmektedir. $\mathrm{Bu}$ amaçla, bölgede önemli bir sorun olmadığını savunan, birlik-beraberlik" mesajlarını ön planda tutan, Çin'in Sincan-Uygur'a verdiği önemi vurgulayan bir içerik göze çarpmaktadır: Milli birlik hepimizin görevi-28.05.2015, Sincan >da toplumsal yatırım teşvik ediliyor-28.05.2015, Sincan da çocuklara kitap hediyesi-28.05.2015, Shenzhen Uluslararası Kültür Fuarı ^ndaki Kaşgar stand1-21.05.2015, Sincan`da 26 temel proje uygulanmaya başlandı-21.05.2015 (http://tr.ts.cn/home/News-List.aspx? \&cid=56). Sitede Türkiye gündeminden haberlere de yer verilmektedir. Türkiye gündeminden haberlerin Türkiyedeki televizyon ve gazetelerden alındığ 1 görülmektedir: Antalya'ya yapılacak yeni havalimanı için yer belirlendi-21.05.2015, Türkiye’nin en büyük gölü Van'da-22.05.2015, Davutoğlu'ndan gençlere müjde-25.05.2015, Şampiyon Galatasaray-26.05.2015, Benzine 6 kuruş indirim-25.05.2015, Türkiyede her 4 kişiye bir araç düşüyor-25.05.2015, Ekonomik güven endeksi açıkland1-28.05.2015 (http://tr.ts.cn/home/ News-List.aspx?\&cid=34\&page $=1$ ).

Çin'in Türkiye toplumuna yönelik çalışmalarında sosyal medyayı da kullandığı, sosyal medyada daha çok geleneksel medya araçları adına açlan hesapların kullanıldığ 1 görülmektedir. GbTimes Türkiye'nin facebook hesabı (https://www.facebook. com/gbtimesturkey?filter=1), CRI Türkçe’nin facebook hesab1 (https://www.facebook.com/pages/CRIT\%C3\%BCrk\%C3\%A7e-Servisi/168508139975104) ve twitter hesabi (https://twitter.com/CRI_Turkish), CTV'nin youtube heab1 (ttps://www.youtube.com/ user/chinatvturkish) aktif olarak kullanılmaktadır.

Çin'in medya alanındaki bir başka çalışması çeşitli ülkelerinden yayın kuruluşlarının temsilcilerini davet edildiği forumlardır. 2015 yılının Mart ayında gerçekleştirilen Borao Asya Forumu'nda "Medya Yöneticileri Yuvarlak Masa Toplantısı" başlığıyla bir toplantı gerçekleştirilmiştir (http://turkish.cri.
cn/741/2015/03/23/Zt1s167208.htm). Toplantiya Türkiye'den TRT temsilcisi ve Yön Radyo yönetim kurulu başkanı Yüksel Mansur Kılınç katılmıştır (Yüksel Mansur Kılınç ile söyleşi, 2015).

\section{Sonuç ve Öneriler}

Uluslararası kamuoyunda yeni bir imaj inşa etmeye çalışan Çin, sert güç kaynaklarını geri planda tutmakta, yumuşak güç kaynaklarını ön plana çıkarmaktadır. Çin yönetiminin, etkili bir biçimde kullandığg 1 yumuşak güç kaynaklarının başında medya gelmektedir. Çin, dünyanın birçok ülkesinde olduğu gibi Türkiyede devlet merkezli medya organizasyonlarını, oluşturduğu yumuşak güç stratejisi çerçevesinde kullanmaktadır. Bu çalışma, Çin’in Türkiye'deki medya çalışmalarına "yumuşak güç" kavramı çerçevesinde yaklaşmaktadır. Çalışmada ulaşılan temel tespitler şöyle özetlenebilir:

1. Çin'in Türkiyedeki medya yatırımlarına ağırlık verdiği 2000'li yıllar, Çin’in "süper güç" olma yolunda adımlar attığı; bu doğrultuda medya alanında dışa açılma stratejisini açılkadığı döneme denk gelmektedir. Başka bir deyişle Türkiye'deki medya yapılanması, Çin'in 2001 yılında açılkadığı medyada "dışa açılma" stratejisiyle uyumludur. Çin'in medya stratejisinin çerçevesinde Türkiye'deki radyo ve dergi gruplarıyla yayın anlaşmaları yapılmış, son olarak Çin kendi televizyonunu, internet sitelerini ve radyosunu devreye koymuştur. Çin medyasından alınan içeriklerin Türkçeye çevrilmesiyle başlayan süreç; yerelleştirilmiş-bölgeselleştirilmiş yayıncılık ve habercilik yapılması için yapılan çalışmalarla sürmektedir.

2. Çin'in Türkiye'deki medya faaliyetlerinin artması, Türkiye ve Çin arasındaki ekonomik, diplomatik ve kültürel ilişkilerin gelişmesiyle paralellik göstermektedir. Çin'in Türkiye'deki medya faaliyetlerinin hızlı bir gelişme gösterdiği 2000 'li yıllar aynı zamanda Türkiye-Çin arasındaki diplomatik ilişkilerin yoğunlaştığı, diş ticaret hacminin 20 milyar doların üzerine çıktığı, kültürel işbirliklerinin yapıldığı dönemdir.

3. Çin'in devlet merkezli yumuşak güç modelinin, Türkiye'deki medya yayınlarına da yansıdığı görülmektedir. Radyolarda, internet sitelerinde yayınlanan haber ve yorumların, bilgilerin büyük 
bir bölümünün merkezi bir sistemle hazırlandığ görülmektedir. Radyolarda ve internet sitelerinde yer verilen haber ve bilgilerin bir bölümü birebir aynıdır. Ağırlıklı olarak CRI'den alınan bazı haberler ise küçük değişiklikler yapılarak yayınlanmaktadır.

4. Çin'in Türkiyedeki medya faaliyetleri biçim ve içerik açısından incelendiğinde, dünyanın diğer ülkelerinde yaptığ 1 yayınlarla benzerlikler olduğu gibi, Türkiye’ye özgü mesajları da içerdiği görülmektedir. Türkiyedeki medya araçlarının yayınları daha çok Çin’in "yumuşak güç" stratejisinin çerçevesinde ve merkezi bir anlayışla yürütülmektedir. Medya içeriklerinde, -özellikle haber bültenleri ve haber yorumlarda- Çin'in barışçl politikalar yürüttügüne, yardımsever ve gelişmiş bir ülke olduğuna vurgu yapmaktadır. Haberlerde ve haber yorumlarda Çin'in uluslar arası sorunlarla ilgili yaklaşımlarına geniş yer ayrılmakta, bu konularda Çinli devlet yöneticilerinin yaptığ 1 açıklamalara yer verilmektedir. Çin'in imajını düzeltmek için yapılan haberler ağırlık taşısa da, bültenlerde Çin'in en büyük rakibi ABD'nin imajını zedelemeyi amaçlayan haberlerin de sık sık yayınlandığı görülmektedir. Söz konusu haberlerde Çinli yöneticilerin ABD’nin uluslararası politikaları aleyhindeki açıklamalarına, İran ve Rusya devlet yetkililerinin ABD'yi eleştiren açılklamalarına ve bazı ülkelerin ABD'nin uluslararası çıkarları aleyhinde aldığı kararlara yer verilmektedir. Ülke imajının oluşturulmasında, geliştirilmesinde medyayı kullanan Çin yönetimi, Türkiye kamuoyuna yönelik mesajlarında ülkede yaşayan "etnik gruplar"la ilgili konulara özel bir önem atfetmektedir. Bunun Türk kökenli etnik bir grup olan Sincan-Uygur Özerk Bölgesi'yle ilgili Türkiye kamuoyundaki hassasiyetten kaynaklandığı düşünülmektedir. Türkiye kamuoyunda oluşan olumsuz imajin ağırlıklı olarak ortadan kaldırabilmek için büyük çaba gösterilmekte, özel yayınlar yapılmaktadır. Türkiye'de bir özel radyo kanalı ile yayın anlaşması yapan ilk Çin radyosunun Sincan-Uygur Özerk Bölgesi Radyosu olması, Sincan Uygur Bölgesinin haber ajansı Tienşen'in Türkçe yayın yapması bu açıdan önemlidir. Etnik gruplarla ilgili konulara ağırlık verilmesinin insan hakları ihlalleri, dinsel gruplara baskı gibi uluslararası kamuoyunda da var olan algının değiştirmeye çalışılmasıyla da ilgisi vardır. Yayınlarda, "İpek
Yolu`nun yeniden canlandırılması" projesinin sıkça dile getirildiği görülmektedir. Söz konusu projenin, İpek Yolu'nun batı ucu olan Türkiye ile siyasi, ekonomik ve kültürel ilişkileri güçlendireceği vurgulanmaktadır. Yayın içeriklerinde ayrıca Çin'deki yatırım, turizm ve ticaret potansiyeline dikkat çekilmekte; Türkiye'deki girişimciler Çin ile ticaret yapmaya teşvik edilmektedir. Türkiye-Çin kültürel işbirliklerine, Çinli firmaların Türkiye'de gerçekleştirdiği hızlı tren projesi gibi projelere de geniş yer ayrılmaktadır. İçeriklerde, Çin tarihi, kültürü, dili ile ilgili bilgilere de yer verilmektedir.

5. Çin'in Türkiye kamuoyuna yönelik yayınlarının etkisi sınırlıdır. Araştırmalara göre, Türkiye kamuoyunun büyük bir bölümü Çin'le ilgili olumsuz bir algıya sahiptir. Çin'in bu sonuçtan yola çıkarak Türkiyedeki medya stratejisinde değişikliğe gittiği görülmektedir. Çin Uluslararası Radyosu Türkçe Servisiınin yaptığı yayınlarıyla yetinmeyen Çin, Türkiyedeki özel radyolarla yayın anlaşmaları yaparak dinleyicilere ulaşmaya çalışmaktadır. Bununla da yetinmeyen Çin yönetimi, Türkiye'de yeni bir radyo kurmak için çalışmalarını sürdürmektedir. Çin strateji değişikliğinin bir parçası olarak radyo yayınlarının yanına televizyon yayıncılı̆̆ını da eklenmiştir. 2014 yılında kurulan CTV Türkçe altyazılı yayın yapmaktadır. Çin, yeni medyayı da son beş yıldır etkili bir biçimde kullanmaktadır. Türkçe yayın yapan çok sayıda internet sitesi ve mobil uygulama bulunmaktadır.

6. Çin’in, okuma alışkanlığının düşük olduğu Türkiye'de gazete-dergi gibi geleneksel medya faaliyetlerini sınırlı bir biçimde yürüttüğü görülmektedir. Çin'in Türkiyede yazılı medya (gazete, dergi) alanındaki tek yayın organı China Today'dir. Dergi ağırlıklı olarak ekonomi haberlerine yer vermektedir. Dergi bunun yanında Çin kültürü, sanatı ve tarihi gibi konularda da okuyucularına bilgi aktarmaktadır.

7. Çin'in Türkiye'deki medya faaliyetlerinin tek taraflı olduğu görülmektedir. Bu durum, Türkiye’nin bu süreçte daha aktif olması gerektiğini ortaya koymaktadır. TRT Arapça, TRT Türk ve TRT Avaz ile yumuşak güç mücadelesine katılan Türkiye'nin, bir tv kanalı veya mevcut kanallardaki programlarla Çin’e yönelik yayınlar yapması gerektiği düşünülmektedir. 


\section{Kaynakça}

Afrikảnın Çin Rüyası. (2013-2014). China Today Türkiye, 8, 58-59.

Akçadağ, E. (2011). Yükselen Güç Çin'in Kamu Diplomasisi. Erişim Tarihi: 02.03.2015, http://www. kamudiplomasisi.org/pdf/cinkamudip.pdf.

Anbo, X, Qian, Z. (2014). Komşuları da Kazançlı. China Today Türkiye, 12, 30-33.

Aslan, T. (2011). Türkiye-Çin İlişkilerinde Büyük Firsat Nasıl Kaçtı. http://odatv.com/n. php? $\mathrm{n}=$ turkiye-cin-iliskilerinde-buyuk-firsatnasil-kacti-2810111200. Erişim Tarihi: 17.04.2015.

Ankara Strateji Enstitüsü. (2012). Türkiye-Çin İlişkileri Raporu, s. 10, Erişim Tarihi: 02.03.2015, http:// www.ankarastrateji.org/_files/24022012160438YMHZ5.pdf

Chengzi, L. (2015). Çin-İtalya Köprüsü. China Today Türkiye, 16, 56-58.

Çavuş, T. (2012). Dış Politikada Yumuşak Güç Kavramı ve Türkiye’nin Yumuşak Güç Kullanımı. Kahramanmaraş Sütçü İmam Üniversitesi İktisadi ve İdari Bilimler Dergisi, 2, 23-37.

Çıplak, E. (2012). Kobiler İçin Büyük Pazar. China Today Türkiye, 1, 19.

Çıplak, E. (2015a). Çin’de Kozmetik Mağazaları Aç1yor. China Today Türkiye, 16, 32-33.

Çıplak, E. (2015b). İstanbul'da Çince Öğretecek. China Today Türkiye, 16, 34-36.

Çolakoğlu, S. (2012). Türkiye-Çin İlişkileri: Tek Taraflı Aşk mı?, Ortadoğu Analiz, 4, 45.

D'Hooghe, I. (2010). The Limits of China's Soft Power in Europe :Beijing's Public Diplomacy Puzzle. Clingendael Diplomacy Paper, 25, Clingendael: Netherlands Institute of International Relations.

Erdal Emre ile söyleşi, 15 Nisan 2015.
Ertekin, B. A. (2012). Uluslararası Sistemde Görselİşitsel Medyanın Kamu diplomasisi ve Kamuoyu Yaratmadaki Önemi: Trt'nin Türkçe Dışında Yayın Yapan Kanalları Üzerine Bir inceleme, Elektronik Sosyal Bilimler, 42, 323-354, Erişim Tarihi: 12.03.2015. http://www.mulkiyedergi.org/esosder/ article/viewFile/5000068546/5000063607.

Fangfang, L. (2014). Tam Gaz Sincan’a. China Today Türkiye, 12, 56-59.

Feng, J., Yaozu L. (2013). Geleneksel Çin Mimarisini Dünyaya Taşıyor. China Today Türkiye, 4, 74-75.

Feng, J. (2014). Çin’de Turizm Ateşi. China Today Türkiye, 12, s. 24-25.

Fook, L. L. (2010). China’s Media Initiatives and International Image Building. International Journal of China Studies, 1 (2), 545-568.

Gagliardone, I., Repnikova, M. ve Stremlau, N. (2010). China in Africa: a New Approach to Media Development?. Report, The Programme in Comparative Media Law and Policy. Oxford: University of Oxford Press. http://www.gazeteciler.com/gundem/ gbtimes-turkiyede-faaliyete-basladi-62000h.html, Erişim Tarihi: 16.04.2015.

Hong, Z., Menzel, V. (2012). Tarımsal Miraslar. China Today Türkiye, 1, 54-57. http://www.hurriyet.com. tr/ekonomi/6904347.asp?gid=196, Erişim Tarihi: 16.04.2015.

Jianmin, W. (2013). Dünyanın Bir Çin Rüyasına İhtiyacı Var. China Today Türkiye, 4, 40-41.

Jirong, Y. (2013-2014). Afrika'da Yatırımlar Artıyor. China Today Türkiye, 8, s. 60-61.

Jun, L. (2015). Etiopya'daki Çin Şirketleri. China Today Türkiye, 16, 46-48.

Kızılca, İ. (2014). Türkiye’nin Çin ile Dış Ticaretinde Bilinmesi Gereken 3 Şey. Türkiye Ekonomi Politikaları Araştırma Vakfi (TAPEV); değerlendirme notu 2014. Erişim Tarihi: 10.04.2015, http://www.tepav.org.tr/ upload/files/13941148381.Turkiye__nin_Cin_ile_ Dis_Ticaretinde_Bilinmesi_Gereken_3_Sey.pdf. 
Kızılocak, E. (2013-2014). Güneş Devi’nin Türkiye Macerası. China Today Türkiye, 8, 34-35.

Köfteoğlu, K. (2012). Türk Girişimcilere Birçok Fırsat Var. China Today Türkiye, 1, 24-27.

Köfteoğlu, K. (2013-2014a). CRI’nin Sesi 56 Yildır Türkiye'de Yankılanıyor. China Today Türkiye, 8. 32-33.

Köfteoğlu, K. (2013-2014b). Dostluğu Pekiştiren Fuar. China Today Türkiye, 8, 24-25.

Köfteoğlu, K. (2013-2014c). Mardin- Çin Hattı. China Today Türkiye, 8, 30-31.

Köfteoğlu, K. (2014). Şimdi İş Yapma Zamanı. China Today Türkiye, 12, 34-35.

Limin, B. (2013-2014). Bulutların Üzerindeki İpekyolu. China Today Türkiye, 8, 26-27.

Lin J. Y. (2013-2014). Çinli Firmalar Enerjinin Yükselen Değeri Oldu, Yatırım, Tüketim ve Mevcut Ekonomik Durum. China Today Türkiye, 8,36-39.

Lintao, Y. (2014). Geleceği İzlemek: Çin-Yunanistan. China Today Türkiye, 12, 60-63.

Meiling, W. (2013-2014). Zunyi Efsanesi. China Today Türkiye, 8, 74-81.

Meiling, W. (2014). Wuzhou: Lingnan'in Unutulmaz Şehri. China Today Türkiye, 12, s. 78-81.

Meiling, W. (2015). Yuxi: İnsanlığın Atasının Evi. China Today Türkiye, 12, 66-69.

Monan, Z. (2015). Avrupa, En Büyük Yuan Pazarı Olma Yolunda. China Today Türkiye, 12, s. 59.

Nelson, A. (2013). CCTV's International Expansion: China's Grand Strategy for Media?. Washington: Report to the Center for International Media Assistance. http://news.xinhuanet.com/english2010/ special/2011-11/28/c_131274495.htm, Erișim Tarihi: 10.04.2015.
Nye, J. (2002). Hard and Soft Power in a Global Information Age. M. Leonard (Ed), Re-Ordering the World içinde. London: The Foreign Policy Centre.

Nye, J. (2005). Yumuşak Güç. Ankara: Elips.

Nye, J. (2010). TED Talks-Joseph Nye on Global Power Shifts, Erişim Tarihi: 01.04.2015. http://www.ted. com/talks/joseph_nye_on_global_power_shifts. html.

Özdemir, H. (2008). Uluslararası İlişkilerde Güç: Çok Boyutlu Bir Değerlendirme. Ankara Üniversitesi SBF Dergisi, 63 (3), 113-144.

Ruili, H. (2015). Ekonomik Canlılığı Teşvik Dönemi. China Today Türkiye, 16, 37-39.

Sak, E. (2014). Kamu Diplomasisi ve Çin Yalova Üniversitesi Barış Araştırmaları ve Çatışma Çözümleri. 2 (1), 9-25. http://www.silktrek.com/, Erişim Tarihi: 29.04.2015.

Shujun, Y. (2013-2014). Ekonomik Büyümede İstikrarlı Toparlanma. China Today Türkiye, 8, 20-22.

Shujun, Y. (2014). Mobilya Pazarında Potansiyel Büyük. China Today Türkiye, 12, 18-19.

Shujun, Y. (2015). Şian: Eski Hazineleri Arayanlar İçin Biçilmiş Kaftan. China Today Türkiye, 16, s. 70-73.

Song, W. (Ağustos-Eylül 2014). İsviçre ile İlişkiler Yeni Zirvelere Taşınıyor. China Today Türkiye, 12, 28-29.

Thussu, D., De-Americanizing Soft Power Discourse?, Erişim Tarihi: 01.04.2015, http://uscpublicdiplomacy.org/sites/uscpublicdiplomacy.org/files/useruploads/u20150/CPDPerspectives2_2014_SoftPower.pdf.

http://tr.ts.cn/home/, Erişim Tarihi: 29.04.2015.

http://tr.ts.cn/home/News-List.aspx?\&cid=56, Erişim Tarihi: 29.05.2015.

h t t p : / / t r.t s.cn/home/News - List. aspx? \&cid=34\&page=1, Erişim Tarihi: 29.05.2015. 
http://turkish.cri.cn/741/2015/03/23/Zt1s167208.htm, Erişim Tarihi: 29.04.2015.

http://turkish.cri.cn, Erişim Tarihi: 14.04.2015.

http://turkish.cri.cn/862/2009/03/27/141s112505. htm, Erişim Tarihi: 15.04.2015.

h t t p : / / t u rkish.china.com/n ew s / ch ina/543/20141023/190506.html, Erişim Tarihi: 22.04.2015.

http://turkish.cri.cn/862/2010/05/11/141s125747. htm, Erişim Tarihi: 29.04.2015.

http://turkish.cri.cn/281/2007/10/30/1@82514.htm, Erişim Tarihi: 15.04.2015.

Türkiye Cumhuriyeti Pekin Büyükelçiliği Bilgi Notu, Erişim Tarihi: 10.04.2015, http://pekin.be.mfa.gov. tr/ShowInfoNotes.aspx?ID=121262,

Uçar, R. B. (2012). Çin’i Keşfetme Zamanı: Dünyanın Yükselen Değeri Çin, Küçük Büyük Bütün Girişimciler İçin Çok Büyük Bir Pasta Sunuyor. China Today Türkiye, 1, 12-18.

Uçar, R. B. (2013). Çinlilerle Ortaklık İçin En Doğru Zaman. China Today Türkiye, 4, 14-19.

Uçar, R. B. (2013-2014). Her Kapıyı Açan Türkler: Çin'den İthalat Yapan, Mal Satan ya da Bu Ülkede İş Kuran Türk Bilgelerle Mutlaka Tanışın. China Today Türkiye, 8, 12-19.

Wang, J. (2011). Introduction: China's Search of Soft Power, Jian Wang, (ed.), Soft Power in China: Public Diplomacy through Communication içinde, (s.118). New York: Palgrave Macmillan.

Wang, H. (2011). China's Image Projection and Its Impact, Jian Wang (ed.), Soft Power in China: Public Diplomacy through Communication, içinde (s. 3756). New York: Palgrave Macmillan.
Wandi, J. (2013-2014). 533 Kilometre Bitiyor: Ankara-İstanbul Hizlı Tren Hatt1 533 Kilometre Uzunluğunda ve İnşası Üç Etapta Tamamlanacak. China Today Türkiye, 8, s. 28-29.

Wandi, J. (2015). 2015’in Kalkınma Hedefleri Belirlendi. China Today Türkiye, 16, 6.

Wenjie, W. (2014). Tian Jiaxin Çin’i Dünyaya Müzikle Tanitiyor. China Today Türkiye, 12, 64-67.

Wingyu, W., Lindan, Z., Xaoyan, Q. (2013). Harbin: Kuzeydoğu Çin’in Buzdan Periler Diyarı. China Today Türkiye 4, 76-79.

Xiaodong, H., Zhongming, P. (2013-2014). Ulusal Sincan Zhundong Ekonomik ve Teknolojik Kalkınma Bölgesi. China Today Türkiye, 8, 72-73.

Xiaofei, D. (2013-2014). Gök Kubbenin Altı. China Today Türkiye, 8, 64-69.

Xiaosheng, G. (2012). Çin-Türkiye Stratejik İşbirliği İlişkisinin Gelişiminin Derinleşmesini Hızlandıralım. China Today Türkiye, 1, 20-21.

Xiaoyan Z. (2015). Dünyanın Fabrikası'ndan Dünyảnın Yatırımcısına. China Today Türkiye, 16, 12-16.

Xuyeing, Z. (2012a). Çay Köylerine Turlar Revaçta, China Today Türkiye,1 44-47.

Xuyeing, Z. (2012b). Çin'in 10 Gözde Sahil Şehri. China Today Türkiye, 1, 72-75.

Ying, X. (2013). 10 Yilda Gerçekleşen Mucize: Uangxi Zhuang Özerk Bölgesi. China Today Türkiye, 4, 80-82.

Yanqiu, Z. (2014). Understand China’s Media in Africa from the perspective of Constructive Journalism, China and Africa Media. Communications and Public Diplomacy Conference. Beijing. Erişim Tarihi: 02.03.2015, http://www.cmi.no/file/2922.pdf. 
Yılmaz, S. (2011). Yumuşak Güç ve Evrimi. Turan Stratejik Araştırmalar, 12, 31-36.

Yılmaz, S. (2012). Kamu Diplomasisi: Başka Halklara Angaje Olmak, Ayaklandırmak. 21. Yüzyılda Sosyal Bilimler, 1, 201-223.

Yick, R. (2015). Chinese "Soft Power" Expands in Africa with CCTV. Global Voices, 23 September 2012, Erişim Tarihi: 02.03.2015, http://globalvoicesonline.org/2012/09/23/chinese-soft-power-expandsin-africawith.

http://www.yonradyo.com.tr/index.php/yazi/urumciden-istanbula-dinleyici-koprusu, Erişim Tarihi: 16.04.2015. http://www.yonradyo.com.tr/index.php/yazi/cindeturkiyeyi-cince-tanitan-tek-internet-sitesi-acildi, Erişim Tarihi: 29.04.2015.

http://www.yonradyo.com.tr/index.php/program/cinden-merhaba, Erişim Tarihi: 25.04.2015.

http://www.yonradyo.com.tr/index.php/yazi/cindeturkiyeyi-cince-tanitan-tek-internet-sitesi-acildi, Erişim Tarihi: 29.04.2015.

Yuan, H. (2015). Dünden Bugüne Çin Çalgıları. China Today Türkiye, 16, 78-82.

Yüksel Mansur Kılınç ile Söyleşi, 5 Nisan 2015.

Zhu, Y. (2012). Two Billion Eyes: The Story of China Central Television. New York: The New Press. 